See discussions, stats, and author profiles for this publication at: https://www.researchgate.net/publication/298800327

\title{
Labour Market Access for Asylum Seekers and Refugees under the Common European Asylum System
}

Article in European Journal of Migration and Law · March 2016 DOI: $10.1163 / 15718166-12342089$

\section{CITATIONS}

1 author:

Franziska Weber

Erasmus University Rotterdam

40 PUBLICATIONS 71 CITATIONS

SEE PROFILE

Some of the authors of this publication are also working on these related projects:

Project Migration View project

Project Behavioural View project
READS

52 


\section{Labour market access for asylum seekers and refugees under the Common European Asylum System}

by Franziska Weber ${ }^{1}$

\section{Abstract}

The paper identifies a policy inconsistency between the EU's asylum and the EU's labour migration policies and makes a call for stronger convergence. The analysis starts off by setting out the EU's current and future economic challenges with a view to its ageing population and low fertility rates, which displays the EU's need for migrants. Two trends can be observed: The lacking success of Europe's highly-skilled regime, ie the Blue Card scheme, casts doubts on the suitability of the EU's labour migration policy and its ability to meet the EU's labour market's needs this way. Labour market access for people that come to the EU to seek asylum on the other hand is subject to quite a number of restrictions. The lack of coordination seems short-sighted. In an attempt to advocate for stronger coherence the paper sets out the rights to access the EU labour market of those who come to the EU as asylum seekers in detail and explores reform potential where these rights can be expanded consistent with the EU's labour market needs. It looks at EU law in general and refers to Germany as an implementation example.

\section{Key words}

Common European Asylum System, labour market access, TCN, asylum seeker, refugee, subsidiary protection scheme, beneficiary of international protection, highly-skilled migrant, Blue card, law and economics

\footnotetext{
$1 \quad$ Prof. Dr. Franziska Weber, LL.M.

Juniorprofessor for Civil Law and Law \& Economics

University of Hamburg - Faculty of Law - Institute of Law and Economics

Hamburg, Germany

Email: franziska.weber@uni-hamburg.de
}

\footnotetext{
I thank Katharina Eisele, Jerg Gutmann, Mark Provera, Manfred Walser and two anonymous referees for valuable comments on an earlier draft of the paper. I wish to thank Malin Hüttmann and Jennifer Broocks for useful research assistance. I am particularly grateful to Alejandro del Valle Suarez, Jean Monnet Chair on "Borders and Immigration» of European Union Law, who invited me for a research visit to the University of Cádiz (spring 2015) where I could learn from his and his colleagues' expertise.

This article was written over the summer 2015. It does not reflect each policy suggestion that has been discussed in the media since but its claim remains valid in the light of the challenges the EU is currently facing.
} 


\section{Introduction}

In the light of ongoing demographic changes, the EU needs migrants to uphold its welfare systems. Whereas the EU's need for migrants is officially recognized when it comes to policy decisions concerning economic migration, ${ }^{2}$ it is rather unheard of when discussing asylum policy at EU level. EU asylum policy and labour/economic migration policy are two historically separate fields. There seems to be, however, a significant overlap with a view to the target group of both policies. ${ }^{3}$ Putting it bluntly, a policy inconsistency can currently be observed in the sense that the EU on the one hand actively (and rather unsuccessfully) seeks to encourage certain labour migration from outside the EU and on the other hand actively (and rather unsuccessfully) seeks to restrict the arrival of asylum seekers. Their rights to access the EU's labour market are, furthermore, subject to quite a number of restrictions. This paper discusses the current degree of labour market permeability of the Common European Asylum system (CEAS) - by illustrating the European minimum rules and using Germany as an implementation example. This sheds light on the legal conditions under which people that come to the EU as asylum seekers may enter the labour market and allows a critical assessment. It comes to the conclusion that the observed incoherence in the two approaches seems short-sighted with a view to the EU's current and upcoming economic challenges and advocates rethinking.

Asylum policy is high on the agenda in the EU these days. A significant increase in asylum applications and dramatic sea arrivals by the Mediterranean Sea call for changes in the current approach. Many arguments for why changes in the CEAS - that was actually only recently revised ${ }^{4}$ - are required, are put forward by human rights, European and

\footnotetext{
${ }^{2}$ See, for instance, Recitals 3-5, 7 of Council Directive 2009/50/EC of 25 May 2009 on the conditions of entry and residence of third-country nationals for the purposes of highly qualified employment (The Blue Card Directive).

${ }^{3}$ The relationship is, for instance, being seriously discussed in Germany.

${ }^{4}$ The current four core legislative documents are: Directive 2011/95/EU of the European Parliament and of the Council of 13 December 2011 on standards for the qualification of third-country nationals or stateless persons as beneficiaries of international protection, for a uniform status for refugees or for persons eligible for subsidiary protection, and for the content of the protection granted (The revised Qualifications Directive); Regulation (EU) No 604/2013 of the European Parliament and of the Council of 26 June 2013 establishing the criteria and mechanisms for determining the Member State responsible for examining an application for international protection lodged in one of the Member States by a third-country national or a stateless person; Directive 2013/32/EU of the European Parliament and of the Council of 26 June 2013 on common procedures for granting and withdrawing international protection (The revised Asylum Procedures directive); Directive 2013/33/EU of the European Parliament and of the Council of 26 June 2013 laying down standards for the
} 
international lawyers. ${ }^{5}$ By reflecting upon the European rules on labour market access for anyone undergoing the EU's asylum procedure, this paper adds a number of important internal market arguments - arguably the core of European integration - to the discussion.

\section{Economic challenges faced by the EU's internal market}

The European population is ageing: life expectancy is increasing; longevity is on the rise and fertility rates are low. ${ }^{6}$ The development of the fertility rates of the European MS over the past years can be retrieved from Eurostat:

reception of applicants for international protection (The revised Reception Conditions Directive). The implementation deadline for the revised Asylum Procedures and Reception Conditions Directives was in July 2015. It turns out that most of the European MS have not implemented these directives yet: Regarding the Revised Receptions Conditions Directive: on $17^{\text {th }}$ August only Latvia, Cyprus and Portugal have implemented the changes; regarding the revised Asylum Procedures Directive, only Portugal has implemented the new legislation according. This information was retrieved from eur-lex. It seems to be not entirely updated, given that, for instance, Germany should be mentioned among those countries that did implement the new legislation. See for the historical development of the CEAS, M. Provera (2013), The Detention of Asylum Seekers in the European Union and Australia - a Comparative Analysis (Wolf Legal Publishers (WLP), Oisterwijk), pp. 44.

${ }^{5}$ See eg H. O'Nions (2014), Asylum - a right denied: a critical analysis of European asylum policy, Farnham [u.a.]: Ashgate.

6 Source: Regions 2020, Demographic challenges for European Regions, Commission of the European Communities, Brussels November 2008. 


\begin{tabular}{|c|c|c|c|c|c|c|c|c|c|}
\hline & 1960 & 1970 & 1980 & 1990 & 2000 & 2010 & 2011 & 2012 & 2013 \\
\hline EU-28() & & & & & & 1.62 & 1.58 & 1.58 & 1.55 \\
\hline Bulgaria & 2.31 & 2.17 & 205 & 1.82 & 1.26 & 1.57 & 1.51 & 1.50 & 1.48 \\
\hline Czech Republic & 2.09 & 1.92 & 2.08 & 1.90 & 1.15 & 1.51 & 1.43 & 1.45 & 1.46 \\
\hline Germany & & & & & 1.38 & 1.39 & 1.36 & 1.38 & 1.39 \\
\hline Estonia & 1.98 & 2.17 & 2.02 & 2.05 & 1.36 & 1.72 & 1.61 & 1.56 & 1.52 \\
\hline Ireland & 3.78 & 3.85 & 3.21 & 2.11 & 1.89 & 2.05 & 2.03 & 2.01 & 1.96 \\
\hline Greece & 2.23 & 2.40 & 2.23 & 1.40 & 1.27 & 1.47 & 1.40 & 1.35 & 1.30 \\
\hline Croatia & ; & & $\vdots$ & & & 1.55 & 1.48 & 1.51 & 1.46 \\
\hline Italy & 2.37 & 2.38 & 1.64 & 1.33 & 1.26 & 1.46 & 1.44 & 1.43 & 1.39 \\
\hline Cyprus & & & & 2.41 & 1.64 & 1.44 & 1.35 & 1.39 & 1.30 \\
\hline Latvia & $:$ & $\therefore$ & : & $:$ & 1.25 & 1.36 & 1.33 & 1.44 & 1.52 \\
\hline Lithuania & $:$ & 2.40 & 1.99 & 2.03 & 1.39 & 1.50 & 1.55 & 1.60 & 1.59 \\
\hline Luxembourg (") & 2.29 & 1.97 & 1.50 & 1.60 & 1.76 & 1.63 & 1.52 & 1.57 & 1.55 \\
\hline Hungary ( & 2.02 & 1.98 & 1.91 & 1.87 & 1.32 & 1.25 & 1.23 & 1.34 & 1.35 \\
\hline Malta & & & 1.99 & 2.04 & 1.70 & 1.36 & 1.45 & 1.43 & 1.38 \\
\hline Slovenia & & $\therefore$ & & 1.46 & 1.26 & 1.57 & 1.56 & 1.58 & 1.55 \\
\hline Slovakia & 3.04 & 2.41 & 2.32 & 2.09 & 1.30 & 1.43 & 1.45 & 1.34 & 1.34 \\
\hline Finland & 2.72 & 1.83 & 1.63 & 1.78 & 1.73 & 1.87 & 1.83 & 1.80 & 1.75 \\
\hline Sweden & & 1.92 & 1.68 & 2.13 & 1.54 & 1.98 & 1.90 & 1.91 & 1.89 \\
\hline United Kingdom & $:$ & & 1.90 & 1.83 & 1.64 & 1.92 & 1.91 & 1.92 & 1.83 \\
\hline Iceland & 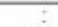 & 2.81 & 2.48 & 2.30 & 208 & 2.20 & 2.02 & 2.04 & 1.93 \\
\hline Liechtenstein & & : & & & 1.57 & 1.40 & 1.69 & 1.51 & 1.45 \\
\hline Norway & & 2.50 & 1.72 & 1.93 & 1.85 & 1.95 & 1.88 & 1.85 & 1.78 \\
\hline Switzerland $\left({ }^{2}\right)$ & 2.44 & 2.10 & 1.55 & 1.58 & 1.50 & 1.52 & 1.52 & 1.53 & 1.52 \\
\hline Montenegro (6) & & ! & : & $!$ & : & 1.70 & 1.65 & 1.72 & 1.73 \\
\hline FYR of Macedonia & : & & & & 1.88 & 1.56 & 1.46 & 1.51 & 1.49 \\
\hline Serbia $\left({ }^{2}\right)$ & $\vdots$ & & : & : & 1.48 & 1.40 & 1.40 & 1.45 & 1.43 \\
\hline Turkey & 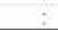 & $\therefore$ & $\because$ & : & $\therefore$ & 2.04 & 2.03 & 2.09 & 2.08 \\
\hline
\end{tabular}

() 2011 and 2012: break in series.

(ग) 2011: break in series.

(2) Breaks in series: 2011 and 2012

(") 2012: break in series.

(3) 2000 and 2010: break in series.

Source: Eurostat (online data code: demo_frate)

One can see that with very few exceptions there has been a constant decrease of fertility rates across the different European Member States (MS). A recent report summarizes the situation as follows:

"The age structure of the EU population is projected to dramatically change in the coming decades due to the dynamics of fertility, life expectancy and migration rates. The overall size of the population is projected to not only be larger by 2060 , but also much older than it is now." ${ }^{7}$

Therefore, crucial changes are expected to the way in which the European population will be structured, the age-wise distribution: ${ }^{8}$

7 European Commission (2014), The 2015 Aging report - Underlying Assumptions and Projection Methodologies, European Economy 8/2014, p. 1.

${ }^{8}$ See Eurostat. 


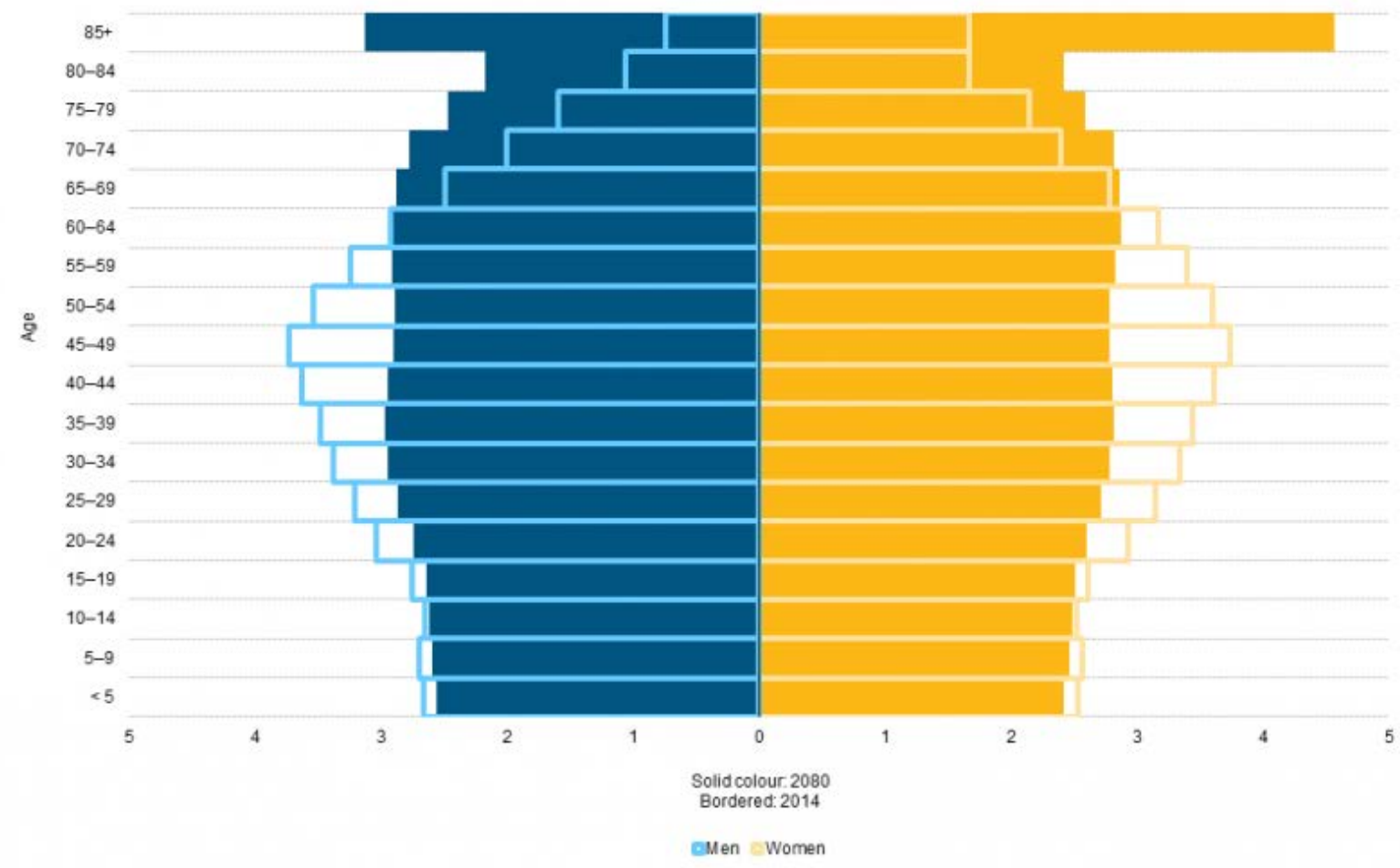

(C) 2080: projections (EUROPOP2013)

Source: Eurostat (online data codes: demo pjangroup and proL_13npms)

This chart reflects the expected situation in the EU in the year 2080. It is characterized by a strong increase in the number of elderly people and relatively fewer working-age people. Overall, it is expected that there will be more people living in the EU, but the age profile will significantly change. The work-age population in the EU has started declining in $2014 .{ }^{9}$ Of course, in assessing these scenarios a number of assumptions are being made, including about net migration. However, even if the exact magnitude of the development varies with different statistics, there is a consensus on the general trend and the need to attract migrants to absorb (part of) its effect. ${ }^{10}$ The scenario poses a threat to EU welfare and the effective working of the internal market. For instance, there is not/will not be a large enough working population to sustain health care and social welfare systems (including eg pension

\footnotetext{
${ }^{9}$ European Commission (2015), Inception Impact Assessment, Review of Directive 2009/50/EC of 25 May 2009 on the conditions of entry and residence of third-country nationals for the purposes of highly qualified employment ("EU Blue Card" Directive), p. 2.

10 European Commission (2014), The 2015 Aging report - Underlying Assumptions and Projection Methodologies, European Economy 8/2014, p. 2 reads that "as a result of these different trends among agegroups, the demographic oldage dependency ratio (people aged 65 or above relative to those aged 15-64) is projected to increase from $27.8 \%$ to $50.1 \%$ in the EU as a whole over the projection period. This implies that the EU would move from having about four working-age people for every person aged over 65 years to two workingage people." For a similar view, see http://prevenblog.com/en/demographic-change-an-emerging-riskfactor-in-europe/; for Germany, see eg H. Brücker (2015), Aktueller Bericht - Mehr Chancen als Risiken durch Zuwanderung, 1/2015 (Institut für Arbeitsmarkt- und Berufsforschung), p.2.
} 
funds) for the rest of the society. ${ }^{11}$ Furthermore, one can also question what will happen to the EU's productivity if the number of available workers is considerably reduced. ${ }^{12}$ The latter point ties in with an aspect that is already a concern for many European countries these days: shortage of skills. For many years already Germany, for instance, has been in need of additional workers for a number of professions, such as engineers, IT experts or doctors. ${ }^{13}$ Furthermore, the shortage is not only applicable in sectors that would typically be qualified as "highly-qualified" but also, for instance, in the care sector (for elderly, in hospitals etc.). ${ }^{14}$ The Commission in 2015 identified the key shortages for the EU in the science, technology, engineering and healthcare sectors. ${ }^{15}$

Having said this for the EU in general it is true that these threats are more pronounced in some European MS than in others. In the aftermath of the financial crisis that particularly hit some of the Southern European countries, a substantial amount of migration has been happening from the South to the North of the EU. ${ }^{16}$ We have also seen an increase in migration from Europe to South-America ${ }^{17}$, for instance. Also, countries that complain about a shortage of skilled workers do have a significant unemployment rate. This begs the question of what happens if such shortages cannot be tackled internally - either by national policies or inner-European migration. This would mean that vocational training could be offered to educate nationals who currently lack certain qualifications. At the same time increased intra-European migration could fill some of the emerging gaps.

\footnotetext{
${ }^{11}$ See also European Commission (2014), The 2015 Aging report - Underlying Assumptions and Projection Methodologies, European Economy 8/2014, pp. 101; see Eurostat conclusions: http://ec.europa.eu/eurostat/statistics-explained/index.php/Population_structure_and_ageing.

12 See European Commission (2014), The 2015 Aging report - Underlying Assumptions and Projection Methodologies, European Economy 8/2014, pp. 4, 77.

${ }^{13}$ Various legislative initiatives and Germans lenient implementation of the Blue Card Directive reflect this. Arguably the shortage was felt even more around 2005 than nowadays, see L. Cerna, The EU Blue Card: Preferences, policies, and negotiations between Member States, Migration Studies, 2:1 2014, p. 88; see CEDEFOP projections on the development of the EU labour market generally, http://www.cedefop.europa.eu/en/publications-and-resources/data-visualisations/labour-force. The exact number of vacancies varies across different studies.

${ }^{14}$ Here, specific bilateral treaties with other countries have been concluded, see eg Agreement on Triple Win Migration between POEA and the German Federal Employment Agency on the placement of Filipino Health Professionals for Employment in the Federal Republic of Germany.

${ }^{15}$ European Commission (2015), Inception Impact Assessment, Review of Directive 2009/50/EC of 25 May 2009 on the conditions of entry and residence of third-country nationals for the purposes of highly qualified employment ("EU Blue Card" Directive), p. 2.

${ }^{16}$ See eg OECD (2012), Recent trends in migration from Greece, Ireland, Portugal and Spain into Germany, OECD Migration Outlook.

${ }^{17}$ See eg IOM (2015), More Europeans Migrate to Latin America, Caribbean than Other Way Around: IOM Study.
} 
The chart as displayed in the beginning reflects the situation in the whole of the EU. It is, therefore, doubtful that the economic challenges the EU faces and to an even more serious extent will be facing, can be solved in an intra-European way. ${ }^{18} \mathrm{~A}$ need to attract third country nationals (TCNs) can safely be stated. ${ }^{19}$ To meet the EU's economic challenges a number of different strategies will have to be employed. Migration from non-European countries is one important part of the solution aside of, for example, inner-European skills programs, youth employment and lifelong learning initiatives. ${ }^{20}$

\section{EU's approach to labour migration}

Over the past years the EU has made it a priority to tackle the aforementioned challenges by seeking in particular to attract so-called highly-skilled labour migrants to come to the EU. MS likewise have own schemes for highly skilled workers. Attracting highly-skilled migrants can be viewed as one of the curcial components of the EU's Lisbon strategy and likewise the follow-up program "Europe 2020". ${ }^{21}$ The EU views itself as having entered the "race for talent" rather late. ${ }^{22}$ As said, the "highly skilled initiative" is not the only EU policy response. The Blue Card Directive can, however, be regarded as one of the cornerstones of the EU initiatives, which considerable effort was invested into. Therefore, evaluating the success of the highly-skilled initiatives can be used as a proxy - even it if is not a perfect measure - to assess Europe's success with its chosen strategy and the attractiveness of the EU for TCNs: Does the EU succeed in attracting TCNs to fill in its labour market shortages?

\footnotetext{
${ }^{18}$ For Germany as a representative of Northern European countries: Eg H. Brücker (2015), Aktueller Bericht Optionen für die Neuregelung der Einwanderung 3/15 (Institut für Arbeitsmarkt- und Berufsforschung), p. 2 states that with the financial crisis being resolved, people will move back to the South of Europe and the new European MS and in Germany there will be more need for TCN workers. He recommends a net migration of 400,000 people/year.

${ }^{19}$ European Commission (2015), Inception Impact Assessment, Review of Directive 2009/50/EC of 25 May 2009 on the conditions of entry and residence of third-country nationals for the purposes of highly qualified employment ("EU Blue Card" Directive) asserts the EU's need for migrants from outside the EU.

${ }^{20}$ See the Agenda for new skills and jobs within Europe 2020, Communication from the Commission to the European Parliament, the Council, the European Economic and Social Committee and the Committee of the Regions, An Agenda for new skills and jobs: A European contribution towards full employment, COM/2010/0682 final.

${ }^{21}$ See L. Cerna (2013) Understanding the diversity of EU migration policy in practice: the implementation of the Blue Card initiative, Policy Studies, 34:2, 180-200, pp. 180; European Commission (2010), An Agenda for New Skills and Jobs: A European Contribution Towards Full Employment, pp. 67; Communication from the Commission to the European Parliament, the Council, the European Economic and Social Committee and the Committee of the Regions, An Agenda for new skills and jobs: A European contribution towards full employment, COM/2010/0682 final, pp. 1, 11.

${ }^{22}$ See among others L. Cerna (2014), The EU Blue Card: Preferences, policies, and negotiations between Member States, Migration Studies, 2:1, p. 73, 74.
} 
Traditionally access to the labour market is within the MS competence; ${ }^{23}$ however, a number of European legislative documents these days regulate the right to work by establishing a number of minimum requirements. ${ }^{24}$ The primary means instituted by the EU is its Blue Card of $2012 .{ }^{25}$ Thereby the EU wishes to attract highly-skilled TCNs. ${ }^{26}$ In order to apply for a Blue Card, an applicant needs to show a work contract or binding job offer with a salary of at least 1.5 times the average gross annual salary paid in the MS concerned (MS may lower the salary threshold to $\mathbf{1 . 2}$ for certain professions where there is a particular need for TC workers). ${ }^{27}$ Other requirements are a valid travel document and depending on the MS a valid residence permit or a national long-term visa, proof of sickness insurance and documents stating professional qualification. If these requirements are fulfilled, within 90 days a Blue Card is granted for an initial period of 1-4 years. Once granted Blue Card holders enjoy, with regard to the job they took up equal treatment with nationals in such aspects as, for example, working conditions, social security, pensions, education and vocational training. After two years of legal employment, they may receive equal treatment with nationals as regards access to any highly qualified employment in the same MS. After 18 months of legal residence, they may move to another MS to take up highly qualified employment (subject to the limits set by the MS on the number of non-nationals accepted). The status is coupled with preferential rules for acquiring long term resident status ${ }^{28}$ and for family reunification. The salary threshold varies with each $M S^{29}$ Whereas the negotiations on the legislative proposal started with the aim of achieving a uniform European standard, in the end MS are left with discretion on a number of matters. They may define a higher salary threshold. They may determine caps on admission volumes. As mentioned, the standard period of validity

\footnotetext{
${ }^{23}$ Also today see Art. 79 (5) TFEU.

${ }^{24}$ See K. Hailbronner (2005), Arbeitsmarktzugang und Anspruch auf soziale Leistungen im europäischen Ausländerrecht, in: Weltinnenrecht, Festschrift für Jost Delbrück (Duncker \& Humblot, Berlin, 315-328) p. 317.

${ }^{25}$ As spelled out in the Blue Card Directive. The implementation deadline ended in July 2011.

${ }^{26}$ See Art. 2(b) Blue Card Directive. "Higher professional qualifications", in turn, means "qualifications attested by evidence of higher education qualifications or, by way of derogation, when provided for by national law, attested by at least five years of professional experience of a level comparable to higher education qualifications and which is relevant in the profession or sector specified in the work contract or binding job offer" (Art. 2(g) Blue Card Directive).

${ }^{27}$ See Art. 5 (1), (3) Blue Card Directive.

${ }^{28}$ If a blue card holder has, for instance, worked in a different MS that time will be added up when calculating whether he or she can apply for long term residence. Art. 16 (3) furthermore sets out that for the purpose of acquiring long term residence they may be absent from EU territory for 12 consecutive months and not more than 18 months in total for the calculation period. This is more favourable than the conditions for other TCNs.

${ }^{29}$ K. Eisele (2013), Why come here if I can go there? Assessing the 'Attractiveness' of the EU's Blue Card Directive for 'Highly Qualified' Immigrants, CEPS Paper in Liberty and Security in Europe No. 60/October 2013, pp. 17 who concludes on p. 25 with suggestions for improvement if the Commission considered a recast.
} 
for the Blue Card can vary between 1 and 4 years. MS can decide whether the application has to be made by the applicant and/or the employer. Importantly, MS have retained an option with a view to applying a labour market test for the vacancy concerned. The EU Blue Card is not the only means to employ highly-skilled TCNs as, in addition, MS have their own systems of national permits for highly skilled migrants. ${ }^{30}$ Hence, we find a co-existence. The German scheme for example was set up first in 2000 in the quest to find IT-experts and with very limited success. ${ }^{31}$ The scheme expired when a number of changes were made to the German Migration Act in 2005 allowing highly-skilled migration more generally ${ }^{32}$ - again with limited success. ${ }^{33}$

The apparent failure of the EU strategy to attract highly-skilled migration can be stated without going into great detail of the different regimes. The numbers speak for themselves. The next table illustrates the amount of highly-skilled workers that were contracted via the

\footnotetext{
${ }^{30}$ See European Commission (2014), Communication from the Commission to the European Parliament and the Council on the implementation of Directive 2009/50/EC on the conditions of entry and residence of thirdcountry nationals for the purpose of highly qualified employment ("EU Blue Card"), p. 4. Highly-skilled TCNs may also come to the EU via the Researchers Directive Council Directive 2005/71/EC of 12 October 2005 on a specific procedure for admitting third-country nationals for the purposes of scientific research OJ L 289, 3.11.2005, p. 15-22

${ }^{31}$ The so-called Green Card, see in particular $\S 4$ (7) und (8) Verordnung über Ausnahmeregelungen für die Erteilung einer Arbeitserlaubnis an neu einreisende ausländische Arbeitnehmer (AnwerbestoppAusnahmeverordnung - ASAV) and $\S 9$ no 2 Verordnung über die Arbeitsgenehmigung für ausländische Arbeitnehmer (Arbeitsgenehmigungsverordnung - ArGV).

${ }^{32}$ See German Migration Law, Zuwanderungsgesetz, Federal Law Gazette I S. 1950.

${ }^{33}$ See table below.
} 


\begin{tabular}{|c|c|c|c|c|c|c|c|}
\hline & \multicolumn{5}{|c|}{ First permits under national schemes } & \multicolumn{2}{|c|}{ Blue Cards } \\
\hline & 2008 & 2009 & 2010 & 2011 & 2012 & 2012 & 2013 \\
\hline Total & 16.157 & 14.980 & 16.999 & 19.604 & 19.988 & 3.664 & 15.261 \\
\hline $\mathrm{BE}$ & 3.577 & 1.202 & 106 & 119 & 98 & 0 & 5 \\
\hline BG & & & & 0 & 0 & 15 & 25 \\
\hline $\mathrm{CZ}$ & & 18 & 0 & 0 & 69 & 62 & 74 \\
\hline $\mathrm{DE}$ & 96 & 119 & 122 & 177 & 210 & 2.584 & 14.197 \\
\hline $\mathrm{EE}$ & & & 0 & 0 & 0 & 16 & 12 \\
\hline EL & 0 & 0 & 0 & 0 & 0 & 0 & 0 \\
\hline ES & 2.884 & 2.071 & 1.244 & 1.650 & 1.136 & 461 & n.y.a. \\
\hline FR & 1.681 & 2.366 & 2.554 & 3.148 & 3.030 & 126 & 304 \\
\hline IT & & & 1.984 & 1.563 & 1.695 & 6 & 112 \\
\hline $\mathrm{CY}$ & 393 & 436 & 634 & 551 & 600 & 0 & 0 \\
\hline LV & & 85 & 114 & 97 & 106 & 17 & 13 \\
\hline LT & & & 138 & 186 & 225 & in force: 2013 & 40 \\
\hline LU & & 96 & 74 & 102 & 21 & 183 & 306 \\
\hline $\mathrm{HU}$ & & & & 0 & 0 & 1 & 3 \\
\hline MT & 0 & 0 & & 0 & 0 & 0 & n.y.a. \\
\hline NL & 6.411 & 4.895 & 5.531 & 5.594 & 5.514 & 1 & n.y.a. \\
\hline AT & 827 & 575 & 668 & 868 & 1.158 & 124 & n.y.a. \\
\hline $\mathrm{PL}$ & & & 12 & & 314 & 2 & 27 \\
\hline PT & 288 & 307 & 342 & 282 & 313 & 2 & n.y.a. \\
\hline RO & & & & 0 & 0 & 46 & 119 \\
\hline SI & 0 & 0 & & 0 & 0 & 9 & n.y.a. \\
\hline SK & & 0 & & 0 & 0 & 7 & 8 \\
\hline $\mathrm{FI}$ & & & & 861 & 748 & 2 & 5 \\
\hline SE & & 2.810 & 3.476 & 4.406 & 4.751 & in force: 2013 & 2 \\
\hline HR & & & & & & in force: 2013 & 9 \\
\hline
\end{tabular}

The EU entered the "race for talent" arguably late and not very successfully. ${ }^{35}$ Except for the case of Germany, the Blue Card system has shown little results only. In essence, almost all Blue Cards granted were issued in Germany. Germany is said to have gone further than the minimum requirements in the Directive when implementing it in making it more favourable to applicants. ${ }^{36}$ This may partly explain the success. Regarding the numbers for Germany, it

\footnotetext{
${ }^{34}$ Source: European Commission (2014), Communication from the Commission to the European Parliament and the Council on the implementation of Directive 2009/50/EC on the conditions of entry and residence of thirdcountry nationals for the purpose of highly qualified employment ("EU Blue Card"), p. 13. Note: the numbers for 2013 are only provisional.

${ }^{35}$ See among others L. Cerna (2014), The EU Blue Card: Preferences, policies, and negotiations between Member States, Migration Studies, 2:1, p. 73, 74; K. Eisele (2013), Why come here if I can go there? Assessing the 'Attractiveness' of the EU's Blue Card Directive for 'Highly Qualified' Immigrants, CEPS Paper in Liberty and Security in Europe No. 60/October 2013, pp. 17. Likewise skeptical regarding the appropriateness of the strategy: Kahanec, M. and Zimmermann, K. F. (2011), High-Skilled Immigration Policy in Europe. DIW Berlin Discussion Paper No. 1096. Available at SSRN: http://ssrn.com/abstract=1767902 or http://dx.doi.org/10.2139/ssrn.1767902.

${ }^{36}$ Only thanks to Germany's implementation it has not been completely irrelevant, see H. Kolb/ S. Fellmer (2015) Vom ,Bremser' zum ,Heizer'? Deutschlands europäische Arbeitsmigrationspolitik, ZAR 3/2015, pp. 105:
} 
has to be subtracted that a certain amount of people are "Statuswechsler" that were already in the country under a different scheme and changed to the Blue Card scheme. The number of Blue Cards issued by Germany in 2014 was 11,848. ${ }^{37}$ When looking at the amount of people that accessed the EU's labour market for highly-skilled via the different national permit schemes, the numbers are not very high either. In comparison to the US, Canada, Australia, the EU cannot prevail. ${ }^{38}$ Here, the migrant's perspective and incentives obviously play a part. ${ }^{39}$ It can among others be identified that the parallel - European and national ${ }^{40}$ schemes may lead to confusion. ${ }^{41}$ There are important language barriers to be overcome when coming to the EU, in particular if one aspires to intra-European mobility. The current European system has not achieved one single permit. National differences prevail and EUwide mobility is only applicable after 1.5 years of employment. It can be questioned how far the procedure was designed with minimal burdens in mind. ${ }^{42}$ There is a close link with the job, which allows potential opportunistic behaviour by employers and puts the immigrants under pressure - for instance if they have recently moved to Europe with their whole family. The Directive allows only a three months unemployment period or no more than two periods of unemployment for the duration of the Blue Card permit before a highly-skilled

Germany is the only country where the Blue Card has gained some kind of importance, this is surprising in the sense that Germany was not very much in favour of facilitating highly-skilled migration - eg blocked EU initiatives in 2001 and slowed down initiatives of 2005. Already when implementing the Blue Card Directive, Germany was making use of much of the flexibility granted in the context of minimum harmonization: eg no labour market test (only a minority of MS did this), and a rather lenient calculation method for the salary requirement. Overall in Germany, the Blue Card enhances and even substitutes the national regime.

37 According to Ausländerzentralregister on 31 December 2014, as calculated by BAMF: http://www.bamf.de/DE/Infothek/Statistiken/BlaueKarteEU/blaue-karte-eu-node.html. Of this amount 4,673 were granted to TCNs newly arriving to Germany. Notably in this statistic the amount of Blue Card holders for 2013 amounts to 11,290 (of which 4,127 newly arrived) [4,018 for 2012 of which 1,557 newly arrived] and hence differs from the numbers available to Eurostat. The Eurostat numbers for 2013 were only preliminary. Additionally the German numbers underlie a different calculation method that only counts people who moved to the EU and obtained a Blue Card in the same year. See also M. Griesbeck (2014), Erleichterung der Fachkräftezuwanderung durch rechtliche Regelungen und flankierende Maßnahmen - eine Zwischenbilanz, ZAR 5-6/2014, p. 183

${ }^{38}$ See K. Eisele (2013), Why come here if I can go there? Assessing the 'Attractiveness' of the EU's Blue Card Directive for 'Highly Qualified' Immigrants, CEPS Paper in Liberty and Security in Europe No. 60/October 2013; Gümüs, Y. K., The EU Blue Card Scheme: The Right Step in the Right Direction, (2010) 12 European Journal of Migration and Law 435.

39 See T. Eger/F. Weber (2014), Immigration Law, in: Encyclopedia of Law and Economics, Backhaus, Jürgen Georg (Ed.), (Springer, New York, 1-11), pp. 1.

${ }^{40}$ This exists in each MS - except for Ireland, England and Denmark that did not implement the Blue Card - see H. Kolb/ S. Fellmer (2015) Vom ,Bremser' zum ,Heizer'? Deutschlands europäische Arbeitsmigrationspolitik, ZAR 3/2015, p. 107.

${ }^{41}$ European Commission (2015), Inception Impact Assessment, Review of Directive 2009/50/EC of 25 May 2009 on the conditions of entry and residence of third-country nationals for the purposes of highly qualified employment (“EU Blue Card" Directive), p. 3.

${ }^{42}$ The EU does not seem to present itself pro-actively as a service provider facilitating job matching, even though some individual employers may do this. 
TCN is sent back to his or her home country. Having said this, given that the directive aims at minimum harmonization, MS may implement it differently and provide conditions more favourable to the immigrants - Germany is among the few countries that have done so. ${ }^{43}$ It has to be added that treating the EU as a whole may conceal some country particularities. Due to the financial crisis, as said, some individual European MS are currently not in need for immigrants but the population is migrating by itself.

It would be too simplistic to claim that there is no TCN migration to the EU and that the EU failed completely in attracting highly-skilled migrants. Indeed, in the context of the classical TCN-scheme, of family reunification, via the Researchers Directive or bilateral treaties that MS conclude, TCNs do enter the EU's labour market. ${ }^{44}$ There may indeed also be highlyskilled migrants among these. The fact that there are "Statuswechsler" in Germany is indicative of this. Overall, the success is, however, limited. The skills shortage remains a concern. The lack of success of the highly-skilled regime can be regarded as indicative of the attractiveness of the EU for TCNs in the context of labour migration. Some doubts can be expressed as to whether the required migrants will actually come to the EU now and even more so in the coming years. Despite having singled out the goal to attract highly-skilled non-European migrants, the instrument, the compromise achieved by the European MS, does not seem to convey this message to the target group. The EU has not given up on its goal to become at least as attractive as the favourite migration destinations Australia, Canada and the USA. ${ }^{45}$ Revising the Blue Card Directive is being discussed, and new policy proposals may include more generous rules for TCN entrepreneurs and service providers. ${ }^{46}$

\section{Labour market permeability in the context of CEAS}

\footnotetext{
43 See H. Kolb/ S. Fellmer (2015) Vom ,Bremser' zum ,Heizer'? Deutschlands europäische Arbeitsmigrationspolitik, ZAR 3/2015.

${ }^{44}$ See M. Provera (2013), The Detention of Asylum Seekers in the European Union and Australia - a Comparative Analysis (Wolf Legal Publishers (WLP), Oisterwijk), p. 20 for details.

${ }^{45}$ See Political Guidelines for the next European Commission, A New Start for Europe: My Agenda for Jobs, Growth, Fairness and Democratic Change, July 2014, pp. 9.

${ }^{46}$ European Commission (2015), Inception Impact Assessment, Review of Directive 2009/50/EC of 25 May 2009 on the conditions of entry and residence of third-country nationals for the purposes of highly qualified employment (“EU Blue Card" Directive), pp. 1. Note that there is no mention of refugees.
} 
As alluded to previously the pool of asylum seekers may merit a deeper analysis in this regard. The scope of who is granted asylum in the different European MS varies. ${ }^{47}$ To start with, all European MS are parties to the 1951 UN Convention - the "Geneva Convention" and the 1967 protocol that stipulates the non-refoulement obligation for refugees as defined in the legislative document. ${ }^{48}$ The CEAS is based upon the Geneva Convention. Hence, the EU has a legal obligation not to violate the principle of non-refoulement. ${ }^{49}$ Individual MS, however, have different interpretations of who to grant beneficiary status to with the minimum being the requirements set out in the Geneva Convention.

Whereas until the mid-1980s the amount of asylum seekers coming to the EU was low and labour market access for those in general possible, the situation changed with the numbers of asylum seekers increasing since the mid-1980s. ${ }^{50}$ Many European MS have rather restrictive policies regulating asylum seekers' access to the labour market these days, ${ }^{51}$ with the upper limit being the minimum harmonization set at EU level. ${ }^{52}$

In the light of the challenges discussed in the foregoing section and the EU's rather pronounced inability to compete for the highly-skilled as an indicator of the EU's prospect in attracting desired TCNs one may question if this approach is constructive and suitable to meet the labour market's demands. The economic challenges the EU is facing are partly unresolved - migrants are and will be lacking. However, there is another - possibly

\footnotetext{
${ }^{47}$ Of the European MS Denmark, Ireland and the UK have opted out of the Common European approach and, hence, have retained their own asylum systems.

${ }^{48}$ According to Article $1 \mathrm{~A}(2)$ a refugee is "a person who is outside his or her country of nationality or habitual residence; has a well-founded fear of being persecuted because of his or her race, religion, nationality, membership of a particular social group or political opinion" and lacks protection in the home country. According to the non-refoulement clause a person cannot be forcibly returned to a territory where he/she may face the risk of persecution.

${ }^{49}$ The European Union has extended the status partly to so-called beneficiaries of "subsidiary protection“. The principle of "refoulement" was officially enshrined in Article 33 of the 1951 Convention Relating to the Status of Refugees and is also contained in the 1967 Protocol Relating to the Status of Refugees and Article 3 of the 1984 Convention Against Torture.

${ }^{50}$ M. Valenta/K. Thorshaug (2013) Restrictions on Right to Work for Asylum Seekers: The Case of the Scandinavian Countries, Great Britain and the Netherlands, International Journal on Minority and Group Rights 20:459-482, p. 460.

${ }^{51}$ See eg ECRE, The EC Directive on the Reception of Asylum Seekers: Are asylum seekers in Europe receiving material support and access to employment in accordance with European legislation? European Council on Refugees and Exiles, Brussels, 2005), p. 16; T.J. Hatton (2013) “Refugee and Asylum Migration", in International Handbook on the Economics of Migration, A. F. Constant, K.F. Zimmermann (eds.), Cheltenham, UK/Northampton, MA, USA: Edward Elgar, 453-469, pp. 461. Some were going in the opposite direction, like Sweden, stressing the desire for asylum seekers to be able to support themselves during the application period, see M. Valenta/K. Thorshaug (2013) Restrictions on Right to Work for Asylum Seekers: The Case of the Scandinavian Countries, Great Britain and the Netherlands, International Journal on Minority and Group Rights 20:459-482, p. 467.

52 See below.
} 
undervalued - group of people actively seeking to come to the EU: asylum seekers. There are no reliable numbers regarding the composition of the group of asylum seekers. However, estimates for Germany state that there is a rather large group with higher qualifications (school and professional). ${ }^{53}$ Some of them may even be highly-skilled. At the same time, there is a large group with no qualifications. An under-represented group seems to be that of middle qualifications. In fact three quarters of the asylum seekers and recognized beneficiaries in Germany are in the working age (15-64) - to be precise $77 \%{ }^{54}$ Effectively, in particular, few asylum seekers are employed. ${ }^{55}$ In the light of the EU's demographic situation this may not be the desirable policy. Labour market access in the context of asylum policy is an area of "significant policy controversy". ${ }^{56}$ Whereas asylum policy and labour migration are traditionally separate, one may question the extent to which this is desirable whenever we are talking about the same target group. Individuals within the group of asylum seekers may have exactly the characteristics that the EU's labour market requires. It is beyond the scope of this paper to write a comprehensive theory on a coherent asylum and labour market policy. Prima facie it seems, however, that in terms of transaction costs with a view to integration efforts and language skills, for example, some arguments could be formed for why a preference to someone who has already spend some time in the country of destination may be preferable over someone who would still need to migrate.

To assess the scope of current interdependencies between the CEAS and labour market access, the next section will set out the extent to which the underlying reasons for why only few asylum seekers and refugees enter the labour market are legal or factual restrictions. It will thereby be illustrated in how far individuals going through or having gone through an

\footnotetext{
${ }^{53}$ See H. Brücker (2015), Aktuelle Berichte - Asyl- und Flüchtlingsmigration in die EU und nach Deutschland (Institut für Arbeitsmarkt- und Berufsforschung) 8/2015, pp. 8. This is one of the few papers that states some data. The German government itself writes in the BT Drucks. 18/6420 on p. 2 that there is no representative data.

${ }^{54}$ H. Brücker (2015), Aktuelle Berichte - Asyl- und Flüchtlingsmigration in die EU und nach Deutschland (Institut für Arbeitsmarkt- und Berufsforschung) 8/2015, p. 10.

${ }^{55}$ For Norway, see M. Valenta/K. Thorshaug (2012), Asylum-seekers' perspectives on work and proof of identity: The Norwegian experience, Refugee Survey Quarterly, 31:2, 76-97, pp. 89, 97; M. Valenta/K. Thorshaug (2013) Restrictions on Right to Work for Asylum Seekers: The Case of the Scandinavian Countries, Great Britain and the Netherlands, International Journal on Minority and Group Rights 20:459-482, pp. 482: asylum seekers have a low rate of employment, irrespective of whether they have formal access to the labour market. Partly this can allegedly be attributed to asylum seekers preferring to first focus on learning the language before finding a "better" job in the host country.

${ }^{56}$ M. Garlick (2013) Asylum-seekers and people in need of international protection, in: Social benefits and migration - a contested relationship and policy challenge in the EU, E. Guild, S. Carrera, K. Eisele (eds.), CEPS, Brussels, 62-81, pp. 75.
} 
asylum procedure can currently enter the EU's labour market. In a next step the scope for extending these rights to better meet the EU's labour market needs will be explored.

\subsection{Labour market access for the different groups of people falling under the CEAS}

In essence, to assess the labour market permeability for people that fall under the CEAS, one can be guided by the different steps in the procedure of Europe's asylum system. To start with asylum seekers are reaching the EU's territory - some of them do in this in legal ways and others fall in the category of "irregular migrants" as it is the case with people fleeing via the Mediterranean Sea. Once within the EU's borders - or in the high sea territory - the next step in applying for asylum is to lodge an application. ${ }^{57}$ For a number of reasons this may not happen immediately, so a first status to be looked at is the pre-lodging-situation (1). The next, obvious, group is asylum seekers that have lodged an application, whose application is hence being processed and who await the decision of the MS authorities (2). Thirdly, there are those whose asylum requests have been granted (3). Importantly, in the EU there is a coexistence of two different statuses. In elaboration of the Geneva Convention the Qualifications Directive speaks of "refugees" on the one hand and includes, furthermore, application procedures for other kinds of international protection given under the term "subsidiary protection". ${ }^{58}$ This applies to asylum seekers who do "not qualify as a refugee but in respect of whom substantial grounds have been shown for believing that the person concerned, if returned [...], would face a real risk of suffering serious harm [...]". ${ }^{59}$ Taken together, both groups form the "beneficiaries of international protection" in the EU. Whereas the revision of the first phase of the $\mathrm{CEAS}^{60}$ had the explicit aim of aligning the two types of status, differences remain. ${ }^{61}$ In order to give an idea of the number of people who are granted the status of "subsidiary protection" recent data is illustrative: In the first half of 2015 the German authorities processed 114.000 asylum applications. 39.552 people were

\footnotetext{
${ }^{57}$ Applications for asylum can be made according to the revised Asylum Procedures Directive on the EU territory, including at the border, in the territorial waters or in the transit zones of the MS.

${ }^{58}$ Council Directive 2004/83/EC of 29 April 2004 on minimum standards for the qualification and status of third country nationals or stateless persons as refugees or as persons who otherwise need international protection and the content of the protection granted, OJ L 304, 30.9.2004, p. 12-23.

${ }^{59}$ Article 2 (e) Council Directive 2004/83/EC of 29 April 2004 on minimum standards for the qualification and status of third country nationals or stateless persons as refugees or as persons who otherwise need international protection and the content of the protection granted, OJ L 304, 30.9.2004, p. 12-23.

${ }^{60}$ These instruments were passed throughout the years 1999-2005. The revised version of the core documents was enacted starting in 2011, with a number of implementation phases ending only in July 2015.

${ }^{61}$ See below.
} 
effectively granted asylum (34.7\%) and additionally 680 people (0.6 \%) were granted subsidiary protection. ${ }^{62}$ Recent German data shows that basically $2 / 3$ of the applications filed for asylum are currently not successful. Some applications are not granted because Germany is not the state responsible for determining the asylum claim under the Dublin system but a different MS is and the case is, therefore, transferred. ${ }^{63}$ This still this leaves a considerable amount of requests that are not honoured (4). For the time until these people have to leave the country, they can be classified as "Geduldete" - being a person with exceptional leave to remain. Who are the people whose application is denied? There is heated discussion about so-called "economic refugees" who leave/have to leave their country due to poor socio-economic and humanitarian living conditions. Many MS do not consider them as potential beneficiaries of international protection under the current EU regime, even though legal arguments to broaden the concept can be made. ${ }^{64}$ In addition, from an economic point of view one can consider them in the context of labour market needs. It is, however, outside the scope of this paper to discuss their status in detail as it would require a thorough incentive and cost benefit analysis.

A last group to consider may be the families of an individual at each stage of the procedure: before lodging, while awaiting the outcome, once recognized as a beneficiary of international protection or denied protection. By exercising the right to family reunification, family members of TCNs enter the EU territory. Again, this paper is only going to consider whether family members are granted a right to work in the EU (5).

Lastly (6) the interrelations between the CEAS and special EU legislation that targets TCNs generally shall be illustrated.

More specifically the different rights are the following:

62 http://www.bamf.de/SharedDocs/Meldungen/DE/2015/20150713-asylgeschaeftsstatistik-juni.html, accessed $28^{\text {th }}$ July 2015.

${ }^{63}$ The Dublin III regulation sets out the details. It distinguishes between legal and illegal migrants seeking asylum and for the case of legal migrants bases the responsibility to assess a complaint on a number of criteria (such as family considerations, recent possession of visa or other titles). In essence, the system comes down to a primary responsibility of the first MS that migrants arrive to being in charge of processing the applications.

64 See once more the numbers referred to above
http://www.bamf.de/SharedDocs/Meldungen/DE/2015/20150713-asylgeschaeftsstatistik-juni.html, accessed $28^{\text {th }}$ July 2015. The EU in addition - for instance Germany - is discussing whether to classify various Balkan countries as "safe countries" to basically allow a collective refusal of asylum requests lodged in an accelerated procedure. 


\section{(1) Situation before lodging asylum request}

European legislation does not make any mention of people that have not yet lodged their application. This, in turn, means that their rights and duties are to be determined by each MS individually.

\section{(2) Asylum seekers}

When it comes to any asylum seeker that has lodged an application the revised Receptions Conditions Directive of 2013 sets out the following rights: Access to the labour market has to be granted no later than 9 months after lodging the application. ${ }^{65}$ The next paragraph restricts the access rather severely when stating that:

"2. Member States shall decide the conditions for granting access to the labour market for the applicant, in accordance with their national law, while ensuring that applicants have effective access to the labour market.

For reasons of labour market policies, Member States may give priority to Union citizens and nationals of States parties to the Agreement on the European Economic Area, and to legally resident third-country nationals."

Effectively an extensive labour market test can be upheld at the discretion of the MS. Generally, the 9 months period may work in tandem with a new requirement for the asylum procedure not to take any longer than 6 months (or 9 months in special cases). ${ }^{66}$ This would, implicitly, ensure that the asylum seeker is not disadvantaged if the procedure takes longer

\footnotetext{
${ }^{65}$ Art. 15. This Directive was downgraded compared to the first Commission proposal: European Commission, Proposal for a Directive of the European Parliament and of the Council laying down minimum standards for the reception of asylum seekers 3 December 2008, COM(2008) 815 final, see M. Provera (2013), The Detention of Asylum Seekers in the European Union and Australia - a Comparative Analysis (Wolf Legal Publishers (WLP), Oisterwijk), pp. 73. The first proposal would have granted access to the labour market after a maximum of 6 months only. After intense discussion, various subsequent amended proposals by the Council were made: Council of the European Union, Outcome of Proceedings of the Asylum Working Party on 6 July 2011, 22 July 2011, Document No. 12580/11; Council of the European Union, Note from Presidency to Asylum Working Party of 26 September 2011, 12 September 2011, Document No. 13102/11; Council of the European Union, Outcome of Proceedings of Asylum Working Party of 6 December 2011, 13 December 2011, Document No. 17832/11; Council of the European Union, Outcome of Proceedings of JHA Counsellors on 23 January 2012, 27 January 2012, Document No. 5515/12; Council of the European Union, Revised Note from Presidency to Permanent Representatives Committee on 22 February 2012, 20 February 2012, Document No. 6394/1/12 Rev 1.

${ }^{66}$ See Art. 31 (3) Revised Asylum Procedures Directive.
} 
than announced or also if going through an appeal procedure: The permission may, as stated in Art. 15 (3), not be "withdrawn during appeals procedures, where an appeal against a negative decision in a regular procedure has suspensive effect, until such time as a negative decision on the appeal is notified." If a negative asylum decision is appealed, apparently, the duration of the procedure is extended. Comparing this provision with the predecessor in the Receptions Condition Directive of 2003, ${ }^{67}$ an improvement can be seen from the asylum seekers' perspective. In the previous version it was stipulated that MS were allowed to determine the period of time upon lodging the application until which the asylum seeker was not allowed to have access to the labour market in Art. 11 (1). Thus, in essence wide discretion was granted. However, note Art. 11 (2): „if a decision at first instance has not been taken within one year of the presentation of an application for asylum and this delay cannot be attributed to the applicant, MS shall decide the conditions for granting access to the labour market for the applicant." This was imposing some restrictions on the MS. Then again, it was not set out specifically how the MS were to grant access to the labour market. The labour market test likewise applied at the discretion of the MS (Art. 11 (4)). Overall, the conditions have become slightly more favourable to asylum seekers. Needless to say MS may go even further than the minimum requirements set out in the new directive. However, when comparing the implementation measures in the MS against the due date $21^{\text {st }}$ July 2015 , one can see that many MS have not implemented the revised Reception conditions directive in time. ${ }^{68}$ There is, hence, EU wide a strong implementation deficit, many MS regulations still only conform with the old regime only ${ }^{69}$ and the MS implementation measures need to be awaited to see how far reaching they are.

In Germany asylum seekers (and "Geduldete") may not work in the first three months. ${ }^{70}$ Then the labour market test-situation kicks in. The German Federal Employment Agency Bundesagentur für Arbeit needs to give permission for the asylum seeker to work. Alternatively, for certain jobs it may be stipulated by regulation that the intervention by the authority is not necessary. After 15 months asylum seekers may work without any

\footnotetext{
${ }^{67}$ Council Directive 2003/9/EC of 27 January 2003 laying down minimum standards for the reception of asylum seekers.

${ }^{68}$ Eur-lex website NIM, accessed on 28th July 2015.

${ }^{69}$ Regarding the implementation measures, see Odysseus (2006), Comparative overview of the implementation of the Directive 2003/9 of 27 January 2003 laying down minimum standards of the reception of asylum seekers in the EU Member States" (Odysseus Academic Network for Legal Studies on Immigration and Asylum in Europe, Brussels).

${ }^{70}$ See Asylum Procedure Act - Asylverfahrensgesetz (AsylVfG) § 61 Erwerbstätigkeit.
} 
restriction. The German rules were changed in 2013 by way of an early implementation of the revised Receptions Conditions Directive. ${ }^{71}$ With abolishing a labour market test for anyone whose procedure takes longer than 15 months, Germany went further than the requirements in the Directive. Apparently, even if after 15 months no labour market test is applicable, asylum seekers may still face a large number of challenges in finding a job, challenges that are beyond legal rights (such as language barriers, no match in qualifications ...). ${ }^{72}$

\section{(3) Beneficiaries of international protection}

Coming to the next group, the recognized beneficiaries of international protection, a stronger right to work is stipulated. Access to the labour market is directly possible and applies without restrictions: They may engage in employed or self-employed activities immediately after protection has been granted (Art. 26). Among others the same conditions for recognition of foreign diplomas apply as for nationals (Art. 28).

Regarding the revised Qualifications Directive of 2011 that sets out these rights the implementation deadline has already passed since $2013 .{ }^{73}$ Previously, the rights for refugees were in essence the same as under the revised regime. However, a differentiation was being made between them and those benefitting from "subsidiary protection" status: For those under the "subsidiary protection" regime a labour market test could be applicable. Access to employment-related education was at MS discretion. A considerable alignment has, hence, happened with the new regime. In Germany, for instance, in line with the European Directive for the group of those under the "subsidiary protection"-regime, since 2013 the German Federal Employment Agency - Bundesagentur für Arbeit is no longer involved and the labour market test was abolished. ${ }^{74}$ So, there are no limits in accessing the labour market in the respective MS from a legal point of view.

\footnotetext{
${ }^{71}$ Federal Law Gazette I p. 3556, Law of 6.9.2013.

72 Indicative: http://www.spiegel.de/wirtschaft/soziales/arbeitsmarkt-bundesagentur-daempft-hoffnung-fuerfluechtlinge-a-1050705.html.

${ }^{73}$ With the exception of Spain and France - however for refugees the rights were the same also under the old regime.

${ }^{74}$ Now: § 31 Beschäftigungsverfahrensordnung (BeschVerfV) - Employment Procedures Order since 1.7.2013.
} 


\section{(4) Application denied}

There is a significant amount of unsuccessful asylum applications. The EU legislation does not specify the labour rights of those whose application was denied. ${ }^{75}$ Often these people do not (immediately) leave EU territory.

When applying for asylum and if the procedure takes longer than 9 months, clearly, everyone - hence also someone with low prospects of being granted international protection - currently has to be granted a right to access the MS respective labour market with the labour market test applying at the MS discretion. In Germany after 15 months in the process, they do likewise not need to pass the labour market test. This situation, for instance, in Germany, stays the same once the application is denied. "Geduldete" is the German term for those whose application was denied, and who enjoy in essence the same rights as asylum seekers. ${ }^{76}$ For how long someone would be in this situation, depends on how long it takes until someone deliberately leaves the country or is deported. Apart from the rules on labour market access, that are the focus of this contribution, other rights eg to some limited social and health care benefits are applicable to them and to any other of the groups discussed. ${ }^{77}$

\section{(5) Family members}

When it comes to the right to family reunification, there is an express provision in the respective directive: ${ }^{78}$ Recognised refugees can apply immediately for family reunification with no minimum period of residence, for instance, being required. "According to Article 14 (1) The sponsor's family members shall be entitled, in the same way as the sponsor, to: [...] (b) access to employment and self-employed activity [...]." Thus, given that refugees have

\footnotetext{
${ }^{75}$ Arguably limits are set through the Employer Sancitons Directive, Directive 2009/52/EC of the European Parliament and of the Council of 18 June 2009 providing for minimum standards on sanctions and measures against employers of illegally staying third-country nationals, OJ L 168, 30.6.2009, p. 24-32.

${ }^{76} \S 32$ (5) Beschäftigungsverfahrensordnung (BeschVerfV) - Employment Procedures Order. The same is true if they switch to the highly-skilled scheme. After 4 years, there is no need to involve the authority at all: § 32 (3) Beschäftigungsverfahrensordnung (BeschVerfV) - Employment Procedures Order.

${ }^{77}$ For an overview, see M. Garlick (2013) Asylum-seeker and people in need of international protection, in: Social benefits and migration - a contested relationship and policy challenge in the EU, E. Guild, S. Carrera, K. Eisele (eds.), CEPS, Brussels, 62-81.

${ }^{78}$ See Council Directive 2003/86/EC of 22 September 2003 on the right to family reunification.
} 
immediate and unlimited access to the labour market, the same applies in principle to the family. Art. 14 (2), however, adds a certain form of a labour market test when specifying that "Member States may decide according to national law the conditions under which family members shall exercise an employed or self-employed activity. These conditions shall set a time limit which shall in no case exceed 12 months, during which Member States may examine the situation of their labour market before authorising family members to exercise an employed or self-employed activity." MS may restrict the right to family reunification to refugees whose family relationships predate their entry. ${ }^{79}$ The refugees' right to family reunification differs from ordinary family reunification adapting it to their special situation. ${ }^{80}$ MS, furthermore, generally have some discretion when it comes to the right to defining who qualifies as a family member and has, therefore, a right to work. ${ }^{81}$

When it comes to family reunification rights of asylum seekers and holders of subsidiary protection status, the rights are far more limited. ${ }^{82}$ Both groups are excluded from the scope of the Family Reunification Directive. A recent 2014 Commission Guidance expresses its favourable position to aligning the status of recognized refugees and holders of "subsidiary protection" status. ${ }^{83}$ Germany has implemented this suggestion. ${ }^{84}$ The Commission Guidance does, however, not comment upon asylum seekers.

\section{(6) Ties with special EU legislation for TCNs}

Regarding the permeability between the Blue Card scheme and the CEAS Art. 3 (b) Blue Card Directive excludes beneficiaries of, and applicants for, international protection from its scope. This, also clearly applies to those not even having lodged an application. On the other hand, the Directive is an instrument of minimum harmonization according to its Art. $4 .{ }^{85}$ The

\footnotetext{
${ }^{79}$ Art. 9 (2).

${ }^{80}$ See. Art. 12. This privilege may elapse if the refugee does not apply for family reunification within 3 months after being granted the status. Generally, the provisions are without prejudice to any family member being granted refugee status (see Art. 9 (3)).

${ }^{81}$ See Art. 4.

82 Excluded according to Art. 3 (2) (a), (c).

83 Communication from the Commission to the European Parliament and the Council on guidance for application of Directive 2003/86/EC on the right to family reunification Brussels, 3.4.2014 COM(2014) 210 final.

${ }^{84}$ See $\S 29$ II Aufenthaltsgesetz (AufenthG) - Residence Act.

${ }^{85}$ Article 4 - More favourable provisions

1. This Directive shall be without prejudice to more favourable provisions of:

(a) Community law, including bilateral or multilateral agreements concluded between the Community or between the Community and its Member States and one or more third countries;
} 
restricted scope of the Blue Card Directive is also expressed in its Art. 10 that sets out the permit needed - valid residence permit or national long stay visa - to make an "in EU" application for a Blue Card which only few exceptions can be granted to and are, furthermore, largely at the discretion of the MS. Germany is discussing an extension of the Blue Card for refugees. ${ }^{86}$ It can be questioned whether Germany has the competence to extending the scheme at all. Arguably, Germany could alternatively expand the national highly-skilled regime due to the explicit exclusion in the Directive. Due to the explicit exclusion, such a measure may not be covered by being a more favourable condition in the context of minimum harmonization. One possibility to overcome this would be revising the Blue Card Directive with a view to including refugees and the like. This is not part of the current discussions at EU level, however. ${ }^{87}$

How does the asylum policy and the right to long-term residence relate? Under the Single Permit Directive the rights and duties of TCN that have come for the purpose of work, study, research or family reunification, except long term residents and highly-skilled workers, are spelled out. ${ }^{88}$ Importantly, the Directive codifies the conditions to acquire long term residence status. Since 2013 newly also beneficiaries of international protection - who were previously excluded from the scope of the directive - may acquire long-term resident status on a similar basis as other TCNs legally residing in the EU for more than five years. ${ }^{89}$ Asylum seekers are excluded from the scope of the Directive..$^{90}$ Given the specific nature of the status of the beneficiaries there is a special arrangement for the calculation of the five years period required. As a basic rule at least half of the period between the date on which the

(b) bilateral or multilateral agreements concluded between one or more Member States and one or more third countries.

2. This Directive shall not affect the right of Member States to adopt or retain more favourable provisions for persons to whom it applies in respect of the following provisions of this Directive:

(a) Article 5(3) in application of Article 18;

(b) Articles 11, 12(1), second sentence, 12(2), 13, 14, 15 and 16(4).

${ }^{86} \mathrm{Eg} \mathrm{http://www.dw.com/en/lawmaker-warns-against-blue-cards-for-asylum-seekers/a-18598620.}$

${ }^{87}$ The latest policy document is European Commission (2015), Inception Impact Assessment, Review of Directive 2009/50/EC of 25 May 2009 on the conditions of entry and residence of third-country nationals for the purposes of highly qualified employment ("EU Blue Card" Directive), pp. 1: There is no mention of refugees.

${ }^{88}$ See Directive 2011/98/EU of the European Parliament and of the Council of 13 December 2011 on a single application procedure for a single permit for third-country nationals to reside and work in the territory of a Member State and on a common set of rights for third-country workers legally residing in a Member State.

${ }^{89}$ Directive 2011/51/EU of the European Parliament and of the Council of 11 May 2011 amending Council Directive 2003/109/EC to extend its scope to beneficiaries of international protection, see the new Arts. 2 (f), 19a.

${ }^{90}$ Art. 3 (2) (c), (d). 
application for international protection was lodged and the date on which it is granted is taken into account. In exceptional cases where the asylum procedure takes more than 18 months, the whole period is to be taken into account. ${ }^{91}$ Importantly the long term residence status is dependent on the beneficiary status. According to Article 9.3a."Member States may withdraw the long-term resident status in the event of the revocation of, ending of or refusal to renew international protection as laid down in Articles 14(3) and 19(3) of Directive 2004/83/EC if the long-term resident status was obtained on the basis of international protection." At the same time there is a special, more protective regime when it comes to expelling beneficiaries of international protection. ${ }^{92}$

\footnotetext{
${ }^{91}$ Art. 4 (2).

${ }^{92}$ See amendments to Art. 12 .
} 


\subsection{Discussion}

Regarding access to the EU labour market differentiations are made between the different groups considered. Once granted the status of "beneficiary of international protection" EUwide, no legal limits are applicable when it comes to access to the respective MS labour market. The same can be true for the families of refugees joining in the context of family reunification. MS may, however, impose restrictions on them. As mentioned, as such it may be more difficult for a TCN to find a job than for a national (due to language barriers, differences in education, cultural barriers, missing university certificates etc.). One remaining question with a view to labour market permeability is concerned with whether beneficiaries of international protection could qualify as Blue Card holders and benefit from this regime. As said, this seems doubtful due to the explicit exclusion, even if the Directive aims at minimum harmonization only. Ways could, however, be imagined to include them, eg. by way of revising the Directive (or extending national labour market schemes). From a labour market policy point of view, such a move seems to be desirable. To assess whether it could be a successful strategy, it is worthwhile to raise the question of what the advantages of the Blue Card regime would be for the migrant compared to the asylum regime: A recognized refugee has full and immediate access to the labour market and has the right to family reunification (with the family having an (at least limited) right to access the labour market, too). A recognized refugee can profit from the long term residence status with special rules for refugees applying in terms of the calculation of the 5 year period. ${ }^{93}$ This status, in general, leads to a rather secure European residence title, stipulating only very few grounds to be expelled. ${ }^{94}$ There are some special rules for all beneficiaries of international protection: On the one hand while protected they cannot be sent back to that state. On the other hand the long term residence status is tied to the need for protection and therefore, can be withdrawn, once the need for protection expires. This is an important downside. All schemes involve renewal periods, both for Blue Card holders as well as holders of refugee status. The initial refugee status is granted for 3 years. A Blue Card may be granted for 1-4 years. The Blue Card regime allows more intra-MS mobility than the long term status

\footnotetext{
${ }^{93} \mathrm{MS}$ again, may make the provision more favourable: see Germany.

${ }^{94}$ The conduct on which expulsion decisions are based must constitute an actual and sufficiently serious threat to public policy or public security. Such decisions may not be founded on economic considerations. EU countries undertake to consider specific factors before taking a decision to expel a long-term resident (age of the person concerned, duration of residence, etc.).
} 
acquired under the Single Permit Directive does. ${ }^{95}$ Overall it seems that permeability to the Blue Card scheme would actually be interesting from the migrants' perspective. A few adaptations may have to be necessary though. One risky element from the migrant's point of view generally is the effect of periods of unemployment. This could not work in the same way with a view to all beneficiaries of international protection as they could not simply go back to their country of origin. Regarding holders of subsidiary protection more specifically the Blue Card scheme may be even more beneficial. To start with under the asylum policy they are granted a permit for only 1 year (upon renewal for at least 2 years). Depending on the MS, Blue Cards can be granted for an initial period for up to 4 years. Holders of subsidiary protection, furthermore, have more limited rights for family reunification and may profit from the Blue Card regime in this respect.

For asylum seekers, whose application is pending, the rights are much more limited. In starting to answer why few asylum seekers effectively work, there are thus not only factual but also legal limits. The sovereignty to decide as to whether a labour market test is upheld rests with each MS. Variations, therefore, exist. This is even more true for anyone who has not lodged the application yet or whose application has been denied. The German rules in this regard were set out. The German rules seem to rest upon the assumption that every asylum seeker immediately applies for asylum and except for the three months barrier no special rules are set out for those who will lodge an application. With the abolition of any restrictions regarding the labour market access for asylum seekers after 15 months - in essence the status being aligned with that of a beneficiary at that point with respect to labour market access - the German system is rather liberal. MS were, however, not required, to do so. For asylum seekers MS may uphold the "labour market test" during the whole period. There is interplay with the duration of the asylum procedure. Due to the high numbers of asylum seekers the systems in some MS are currently overburdened. In Germany the average duration in the first half of 2015 was 5.3 months. ${ }^{96}$ However, there are strong variations depending on the country of origin of the applicant. For some applicants waiting times regularly exceed even the 9 months period. In the light of an all time high that

\footnotetext{
${ }^{95}$ Art. 18 (1) Blue Card Directive vs. Art. 11 Single Permit Directive.

${ }^{96}$ http://www.tagesschau.de/inland/asylverfahren-109.html According to BAMF data.
} 
is expected with a view to asylum applications in 2015 , this number is likely to rise. ${ }^{97}$ In other countries the duration is even longer. Also, with the systems being overburdened, people for a longer time may be in a situation in which they have not even filed an application yet. Under the current rules - also in Germany - this may extend the period during which there is effectively no access to the labour market.

Asylum seekers do not have any rights in the context of family reunification when it comes to family members not being on EU territory. ${ }^{98}$ Coming back to the Blue Card regime and whether it may be beneficial for individuals, there is something to be said in favour of a preference for the Blue Card scheme over the status of asylum seeker: The benefits for an asylum seeker to switch to the blue card scheme are rather obvious as this allows them to immediately get rid of such restrictions as "labour market tests", and acquire rights to family reunification and mobility. Needless to say the status is also preferable to the situation which one is in before lodging the asylum application.

Scholars are discussing transaction costs arguments and a lower burden for the asylum system, if a rechanneling to labour market schemes is possible. ${ }^{99}$ It would help ensure faster asylum procedures for those that fulfill the legal requirements. In a similar vein, classifying countries as "safe countries" which allows for faster procedures is discussed. ${ }^{100}$ A clearer system - possibly more liberal - to allow labour migration may arguably reduce the incentives of people with low prospects to be granted asylum to come to the EU via the asylum regime. ${ }^{101}$ Something may be said for the case of asylum seekers (even with low prospects of being granted asylum) that could carry out highly-qualified work but lacked awareness of the Blue Card scheme when coming to Europe. In this regard it has been referred to the estimations on the composition of the group of asylum seekers. The lack of success of the EU's highly-skilled strategy has, furthermore, by way of example been outlined in detail. Again, one would have to question the legal boundaries of expanding the

\footnotetext{
${ }^{97}$ http://www.handelsblatt.com/politik/deutschland/neue-fluechtlingsprognose-bis-zu-750-000-asylbewerberin-diesem-jahr/12200244.html.

${ }^{98}$ Some rights on the basis of the principle of family unity do exist under the Dublin regulation if family members are spread over various MS, see its recitals 14 and following and Art. 10.

${ }^{99} \mathrm{H}$. Brücker (2015), Aktueller Bericht - Asyl- und Flüchtlingsmigration in die EU und nach Deutschland (Institut für Arbeitsmarkt- und Berufsforschung) 8/15, p. 16. Allegedly this is done in Sweden.

$100 \mathrm{Eg}$ very heavily in Germany. A more restrictive asylum law has recently been passed: Asylverfahrensbeschleunigungsgesetz, published in Bundesgesetzblatt 2015: I No. 40, Bonn, 23 October 2015, pp. 1722. It entered into force on 24 October 2015.

${ }^{101}$ H. Brücker (2015), Aktueller Bericht - Asyl- und Flüchtlingsmigration in die EU und nach Deutschland (Institut für Arbeitsmarkt- und Berufsforschung) 8/15, p. 15.
} 
scheme given that the Blue Card explicitly excludes certain groups of people. Either way MS could easily include anyone under the national permit schemes for highly skilled roles. Having talked about highly-skilled, the same case could possibly be made for any other schemes for economic migrants that could not be dealt with in detail in this paper. The EU's need for migrants is not limited to the highly-skilled. ${ }^{102}$ Whereas there are, hence, a number of supportive arguments for aligning asylum and labour market policies to the extent that they deal with the same target group, some caution is likewise required. The open or restrictive way in which access to the EU's labour market is granted does not only have an impact on asylum seekers currently on EU territory but also for prospective migrants to come. When redesigning asylum policy with a view to the EU's labour market needs, it has to be kept in mind that the EU from an economic point of view does not have an unlimited capacity to employ people but it does, however, have a legal obligation to grant protection to those whore are in its territory and need it. Reforms, therefore, have to be carefully drafted. Having said this, current evidence as to whether refugees take into consideration access to labour market at all when migrating allots only a minor role to such considerations. ${ }^{103}$ They have little knowledge about conditions (including work permits etc.) in the host countries. ${ }^{104}$ However, abusive behaviour by migrants, possibly counting on overstaying the (unsuccessful) asylum procedure is a concern in the MS. ${ }^{105}$ Note lastly that

\footnotetext{
${ }^{102}$ For Germany also the need for non-qualified workers is confirmed, H. Brücker (2015), Aktueller Bericht Asyl- und Flüchtlingsmigration in die EU und nach Deutschland (Institut für Arbeitsmarkt- und Berufsforschung) $8 / 15$, p. 15. In Germany there is discussion on whether an exception should be formulated to the recently introduced rules on the minimum wage.

${ }^{103}$ See J.P. Brekke \& M. Aarset, Why Norway? Understanding Asylum Destinations, Report, Oslo, Institutt for samfunnsforskning (ISF), 2009, available at: www.samfunnsforskning.no/content/download/23142/ 544824/file/R_2009_12_web.pdf (last visited 24 Jan. 2012); Jørgensen \& Meret, "Irregular Migration"; Andersson \& Nilsson, "Asylum Seekers"; Valenta et al., Asylsøkeres rett; see for an analysis of empirical literature on incentives of refugees and countries regulating migration, J. Gutmann (2015) The Economic Analysis of Refugee Law, Hamburg Law Review 15:2, 41-48. Worsening the living conditions in the receiving countries did not have an effect on the inflow of asylum seekers, limiting labour market access was found to increase property crimes according to one study by Bell, Brian, Francesco Fasani and Stephen Machin (2013). Crime and Immigration: Evidence from Large Immigrant Waves. The Review of Economics and Statistics 95(4):1278-90. This finding casts some doubt on the desirability of restricting access to the labour market. See also the studies referred to by T.J. Hatton (2013) "Refugee and Asylum Migration", in International Handbook on the Economics of Migration, A. F. Constant, K.F. Zimmermann (eds.), Cheltenham, UK/Northampton, MA, USA: Edward Elgar, 453-469, pp. 463.

104 M. Valenta/K. Thorshaug (2012), Asylum-seekers' perspectives on work and proof of identity: The Norwegian experience, Refugee Survey Quarterly, 31:2, 76-97, p. 85.

${ }^{105}$ See M. Valenta/K. Thorshaug (2013) Restrictions on Right to Work for Asylum Seekers: The Case of the Scandinavian Countries, Great Britain and the Netherlands, International Journal on Minority and Group Rights 20:459-482, p. 462 refer to the potential "pull effect" of a liberal strategy.
} 
granting access to the labour market generally saves people from the risks of joining black labour markets. ${ }^{106}$

\section{Conclusion}

The paper starts off by setting out the EU's current and future economic challenges with a view to the ageing population and low fertility rates - demographic change. Two trends can be observed: Firstly that of a lack of success of Europe's highly-skilled regime is an indicator of a lack of success of the EU's labour migration policy when targeting non-Europeans. To put it bluntly, the EU may not be so interesting for TCNs to migrate to work after all. And secondly that labour market access for people that come to the EU to seek asylum on the other hand is subject to quite a number of restrictions. The paper went on to setting out the rights and limits of labour market access for asylum seekers and beneficiaries of international protection, the same as for those who have not lodged their application yet or those whose application was denied and their families.

There are strong rights to work in the EU for beneficiaries of international protection, for both, those profiting from refugee status and those benefitting from subsidiary protection schemes. Access for asylum seekers, those that have not even filed their application and those whose application was denied are typically severely restricted under EU legislation. MS are, however, left with a considerable amount of discretion when it comes to granting asylum seekers better rights than those made available under EU legislation. It was mentioned that most EU MS have not implemented some of the revised Directives yet. MS may, furthermore, also treat beneficiaries of international protection even better than EU legislation requires and align the status of recognized beneficiaries of subsidiary protection and recognizes refugees more than EU legislation does (eg in the context of family reunification). Germany's response was exemplified. There seem to be limits to expanding the Blue Card scheme for all the groups considered, given the explicit exclusion from the scope of the Directive. Accessibility of national highly-skilled or other workers' schemes is possible at all times.

\footnotetext{
${ }^{106}$ See M. Valenta/K. Thorshaug (2013) Restrictions on Right to Work for Asylum Seekers: The Case of the Scandinavian Countries, Great Britain and the Netherlands, International Journal on Minority and Group Rights 20:459-482, p. 462.
} 
MS put forward a number of arguments for why the access to the labour market should be restricted for asylum seekers, refugees etc. ${ }^{107}$ In the light of the formulated policy inconsistency one may question whether the need for migrants that is a given in the EU should not play a stronger role in formulating the asylum policy and the possibilities of accessing the labour market thereby acquired. ${ }^{108}$ Given the EU's failure to attract the desired migrants via its labour migration policies, a more favourable approach towards those migrants who actively come to the EU may be fruitful. The current policy seems shortsighted in the light of the upcoming challenges and the EU's need for migrants. This may not only be true for the highly-skilled strategy that was used to illustrate the (doubtful) degree of the EU's attractiveness but also for other economic migrants. The skills shortage does not only extend to highly-qualified work. This paper, hence, pleads for considering the broad picture of an EU in need of migrants - now and in the future - also when formulating asylum policy. It warns against overly deterring migrants that the EU is actually in need of. The paper sought to disentangle a policy inconsistency, rising awareness that both policies - asylum and labour migration - may to quite some extent be addressing the very same people.

EU Migration policy is a highly complex field that requires a careful weighing of many stakeholders' interests to avoid unintended consequences. In this exercise the observed policy inconsistency should find more attentive ears at EU level.

\footnotetext{
107 See discussions in the context of downgrading the first Commission proposal to amend the Receptions Conditions Directive, as referred to above.

108 Brücker, for instance, has calculated a scenario, estimating how many people would enter the German labour market with which level of qualifications, see H. Brücker (2015), Aktueller Bericht - Asyl- und Flüchtlingsmigration in die EU und nach Deutschland (Institut für Arbeitsmarkt- und Berufsforschung) 8/15, p. 10.
} 